\title{
EFFICACY OF SPIROTETRAMAT IN THE CONTROL OF THE CURRANT-SOWTHISTLE (HYPEROMYZUS LACTUCAE L.) ON BLACKCURRANT PLANTATIONS IN POLAND
}

\author{
Barbara H. ŁABANOWSKA*1 ${ }^{1}$, Mirosław KORZENIOWSKI ${ }^{2}$, Tomasz GASPARSKI ${ }^{2}$ \\ ${ }^{1}$ Research Institute of Horticulture, Konstytucji 3 Maja 1/3, 96-100 Skierniewice, Poland \\ ${ }^{2}$ Bayer CropScience, Al. Jerozolimskie 158, 02-326 Warsaw, Poland \\ e-mail: Miroslaw.Korzeniowski@bayer.com
}

Received: October 7, 2013; Accepted: December 23, 2013

\begin{abstract}
Spirotetramat applied as Movento $100 \mathrm{SC}$ at dose rates: 0.7 and $1.0 \mathrm{~L} \cdot \mathrm{ha}^{-1}$ in a single treatment just after blossom resulted in a very high reduction of currant-sowthistle aphid - Hyperomyzus lactucae L. (Aphidoidea, Aphididae) on blackcurrants 'Ojebyn' and 'Titania'. The results obtained with this pesticide applied at both tested dose rates: 0.7 and $1.0 \mathrm{~L} \cdot \mathrm{ha}^{-1}$ were comparable. The efficacy of spirotetramat at $7^{\text {th }}$ day after treatment was similar or slightly poorer compared to standard insecticides, but at $21^{\text {st }}$ day after treatment a higher reduction of aphids than with reference insecticides such as pirimicarb (Pirimor $500 \mathrm{WG}$ at the rate $0.75 \mathrm{~kg} \cdot \mathrm{ha}^{-1}$ ), thiacloprid (Calypso $480 \mathrm{SC} 0.15 \mathrm{~L} \cdot \mathrm{ha}^{-1}$ ) and thiamethoxam (Actara $25 \mathrm{WG}$ at the rate $0.1 \mathrm{~kg} \cdot \mathrm{ha}^{-1}$ ) was recorded. With regard to environment safety and biodiversity it must be underlined that on plants treated with Movento 100 SC, high populations of Coccinellidae (both larvae and beetles), Syrphidae (larvae) and Phytoseiidae were noted.
\end{abstract}

Key words: blackcurrant, aphids, Hyperomyzus lactucae, chemical control, spirotetramat, Movento 100 SC, thiacloprid, Calypso 480 SC, thiamethoxam, Actara 25 WG, pirimicarb, Pirimor 500 WG

\section{INTRODUCTION}

Currants, mainly blackcurrant, are economically important crops in Poland. Fruits are a very rich source of vitamin $\mathrm{C}$ and anthocyanin's. In Northern Europe, many pests are feeding on blackcurrants. Mitchell et al. (2011) in the review article mentioned 12 key pests on both, currants and gooseberry. This group includes several species of aphids. Also in Poland, few species of aphids were noted as currant and gooseberry pests, mainly the currantsowthistle aphid Hyperomyzus lactucae (L.), the European currant aphid Aphis grossulariae (Kalt.), and the red currant blister aphid Cryptomyzus ribis (L.).

Aphids overwinter as eggs on plants shoots. After hatching in spring, they start to feed on buds and young leaves. Later they expand to the tips of young shoots, feed on the underside of leaves and young, green shoots, causing characteristic distortions. The natural enemies of aphids are adults and larvae of ladybirds, lacewing larvae, anthocorids and other beneficial species (Wnuk \& Medvey 1986; Wojciechowicz-Żytko 2009; Mitchell et al. 2011; Wojciechowicz-Żytko \& Jankowska 2011). They control aphid population on currants to some extent, but chemical control is also necessary (Mitchell et al. 2011). Some studies on controlling adult aphids in autumn were performed by Cross et al. (2010). Promising results in the control of aphids and other pests were obtained using the new product - spirotetramat as Movento 100 SC, developed and introduced by Bayer CropScience (Cantoni et al. 2008). Application of Movento 100 SC also reduced pear psylla population (Cacopsylla pyri L.) on pear trees (Jaworska et al. 2012) and strawberry mite (Phytonemus pallidus Banks, syn. Tarsonemus fragariae Zimm.) on strawberries (Labanowska 
et al. 2013). In Poland, aphids were controlled on numerous currant plantations, before or just after blossom. Nowadays, the control of aphids on plants in our country is possible with the use of several active substances but only two of them (besides pyrethroids) are registered and recommended for use in the blackcurrant crop. In this group are thiacloprid as Calypso $480 \mathrm{SC}$ and pirimicarb as Pirimor $500 \mathrm{WG}$.

The aim of this study was to evaluate the efficacy of a new product - spirotetramat as Movento $100 \mathrm{SC}$ to control aphid population on blackcurrant crops in Poland.

\section{MATERIAL AND METHODS}

Three experiments were conducted in 20102011 on blackcurrant plantations: one on 'Ojebyn' and two on 'Titania' cv. The study was carried out on 8- to 9-year-old blackcurrant privately owned plantations in Central Poland. The experiments were established in the randomized block (plots) design with seven replicates. One plot constituted a $10 \mathrm{~m}$ long blackcurrant row. Spirotetramat at a dose rate $70 \mathrm{~g}$ and $100 \mathrm{~g} \cdot \mathrm{ha}^{-1}$ (given as insecticide Movento $100 \mathrm{SC}$ at $0.7 \mathrm{~L}$ and $1.0 \mathrm{~L} \cdot \mathrm{ha}^{-1}$ ) was applied as a single treatment just after the blossom of blackcurrants $\left(19^{\text {th }}\right.$ of May 2010 and $19^{\text {th }}$ of May 2011), at the time when aphids colonies start to build up. Insecticides: pirimicarb at $375 \mathrm{~g} \cdot \mathrm{ha}^{-1}$ (given as Pirimor $500 \mathrm{WG}$ at $0.75 \mathrm{~kg} \cdot \mathrm{ha}^{-1}$ ), thiacloprid at $72 \mathrm{~g} \cdot \mathrm{ha}^{-1}$ (as Calypso 480 $\mathrm{SC}$ at the dose $0.15 \mathrm{~L} \cdot \mathrm{ha}^{-1}$ ) and thiamethoxam at 25 $\mathrm{g} \cdot \mathrm{ha}^{-1}$ (as Actara $25 \mathrm{WG}$ at the dose $0.1 \mathrm{~kg} \cdot \mathrm{ha}^{-1}$ ) were used as reference products.

The pesticides were applied with a motorized knapsack sprayer "Stihl SR 420" at a spray volume of $750 \mathrm{~L} \cdot \mathrm{ha}^{-1}$. The number of live aphids was evaluated just before treatment and at $3^{\text {rd }}, 7^{\text {th }}, 14^{\text {th }}$ and $21^{\text {st }}$ day after the treatment $\left(22^{\text {nd }}, 26^{\text {th }}\right.$ of May and $2^{\text {nd }}, 9^{\text {th }}$ of June $2010 ; 22^{\text {nd }}, 26^{\text {th }}$ of May and $3^{\text {rd }}, 9^{\text {th }}$ of June 2011). Live aphids were counted under stereoscopic microscope in the laboratory on three apical shoots per plot (one shoot from one bush), collected in the field from each of the 7 replicates ( 21 shoots for each treatment) at every observation date. The numbers of aphids in all the counting dates are given in the Tables 1-3. The efficacy of treatment was calculated according to Abbott's formula A $-\mathrm{B} / \mathrm{A} \times$ $100 \%$, where $A$ is the total number of live larvae in control plants and B is the total number of live larvae on treated plants.

\section{RESULTS AND DISCUSSION}

The assessment of aphids prior to treatment in the year 2010 revealed the presence of $100-120$ adults on each apical shoot. In the year 2010 (Experiment I) spirotetramat at the dose rate $70 \mathrm{~g} \cdot \mathrm{ha}^{-1}$ used on blackcurrant 'Ojebyn' was very effective in the control of the currant-sowthistle aphid (Table 1, Fig. 1). Its efficacy was $96.3-100 \%$, depending on the check date and was comparable with the reference product - pirimicarb.

In the two experiments on blackcurrant 'Titania' conducted in 2011, spirotetramat reduced the number of the currant-sowthistle aphid at both dose rates of 70 or $100 \mathrm{~g} \cdot \mathrm{ha}^{-1}$ (Tables $2 \& 3$, Figs. $2 \& 3$ ). In Experiment II, the efficacy of this insecticide was $75-91 \%$ at $3^{\text {rd }}$ and $7^{\text {th }}$ day after treatment, depending on the rate and date of observation (Fig. 2). Efficacy, assessed two and three weeks after treatment, was much higher, up to $100 \%$, at both dose rates in comparison with the reference insecticides - thiacloprid and thiamethoxam.

Table 1. Number of live currant-sowthistle aphid (Hyperomyzus lactucae L.) on blackcurrant 'Ojebyn' after pesticide treatment, Experiment I (Mokra Lewa 2010)

\begin{tabular}{lccrcr}
\hline \multirow{2}{*}{ Treatment } & $\begin{array}{c}\text { Rate of active } \\
\text { compound } \\
\left(\mathrm{g} \cdot \mathrm{ha}^{-1}\right)\end{array}$ & \multicolumn{2}{c}{ No. of aphids per one apical shoot on $3^{\text {rd }}, 7^{\text {th }}, 14^{\text {th }}$ and $21^{\text {st }}$ day } \\
\cline { 3 - 6 } & - & 3 & 7 & 14 & 21 \\
\hline Control - untreated & 70 & $286.3 \mathrm{c}^{* *}$ & $71.1 \mathrm{~b}$ & $106.3 \mathrm{~b}$ & $8.1 \mathrm{~b}$ \\
Spirotetramat & 375 & $10.7 \mathrm{~b}$ & $0 \mathrm{a}$ & $0 \mathrm{a}$ & $0.1 \mathrm{a}$ \\
Pirimicarb & $0 \mathrm{a}$ & $0 \mathrm{a}$ & $0 \mathrm{a}$ & $0 \mathrm{a}$ \\
\hline
\end{tabular}

* Date of treatment $-19^{\text {th }}$ of May 2010

**Means followed by the same letter in each column are not significantly different (Newman-Keuls test, $\mathrm{p}=0.05$ ) 


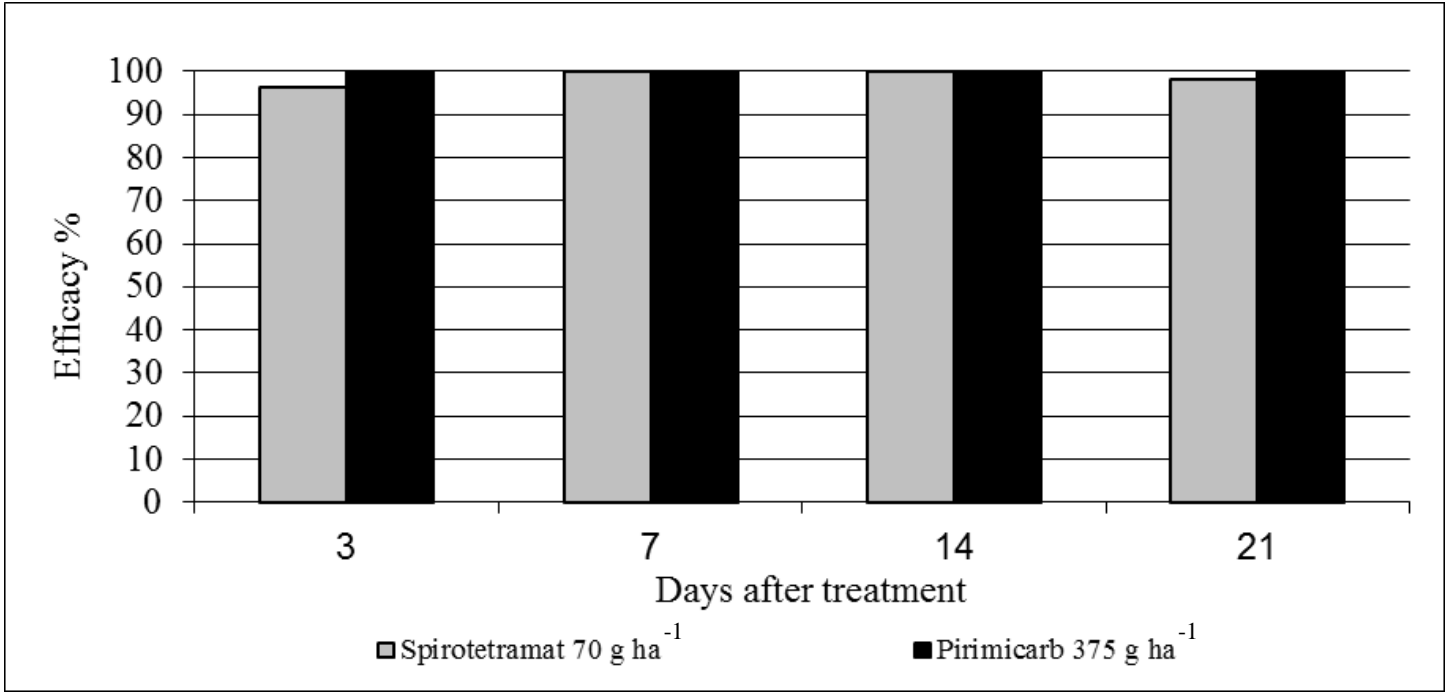

Fig. 1. Efficacy of pesticide treatment in controlling of aphid (Hyperomyzus lactucae L.) at different check dates after treatment, according to Abbott's formula, Experiment I (Mokra Lewa 2010)

Table 2. Number of live currant-sowthistle aphid (Hyperomyzus lactucae L.) on blackcurrant 'Titania' after pesticide treatment. Experiment II (Kwasowiec 2011)

\begin{tabular}{|c|c|c|c|c|c|c|}
\hline \multirow{2}{*}{ Treatment } & \multirow{2}{*}{$\begin{array}{l}\text { Rate of ac- } \\
\text { tive com- } \\
\text { pound } \\
\left(\mathrm{g} \cdot \mathrm{ha}^{-1}\right)\end{array}$} & \multirow{2}{*}{$\begin{array}{l}\text { No. of } \\
\text { aphids/1 api- } \\
\text { cal shoot be- } \\
\text { fore treatment }\end{array}$} & \multicolumn{4}{|c|}{$\begin{array}{c}\text { No. of aphids per one apical shoot on } 3^{\text {rd }}, 7^{\text {th }}, 14^{\text {th }} \text { and } 21^{\text {st }} \\
\text { day after treatment* }\end{array}$} \\
\hline & & & 3 & 7 & 14 & 21 \\
\hline Control - untreated & - & 74.0 & $129.3 b^{* *}$ & $97.4 \mathrm{c}$ & $180.3 \mathrm{~b}$ & $14.9 \mathrm{~b}$ \\
\hline Spirotetramat & 70 & 92.8 & $14.6 \mathrm{a}$ & $23.8 \mathrm{bc}$ & $2.0 \mathrm{a}$ & $0 \mathrm{a}$ \\
\hline Spirotetramat & 100 & 71.0 & $17.2 \mathrm{a}$ & $15.8 \mathrm{~b}$ & $3.9 \mathrm{a}$ & $0 \mathrm{a}$ \\
\hline Thiacloprid & 72 & 79.7 & $9.9 \mathrm{a}$ & $25.3 \mathrm{bc}$ & $21.3 \mathrm{a}$ & $2.9 \mathrm{ab}$ \\
\hline Thiamethoxam & 25 & 99.7 & $8.2 \mathrm{a}$ & $4.1 \mathrm{a}$ & $5.8 \mathrm{a}$ & $3.0 \mathrm{ab}$ \\
\hline
\end{tabular}

*Date of treatment - 19.05.2011

**Means followed by the same letter in each column are not significantly different (Newman-Keuls' test, $\mathrm{p}=0.05$ )

Table 3. Number of live currant-sowthistle aphid (Hyperomyzus lactucae L.) on blackcurrant 'Titania' after pesticide treatment. Experiment III (Zglinna Mała 2011)

\begin{tabular}{|c|c|c|c|c|c|c|}
\hline \multirow{2}{*}{ Treatment } & \multirow{2}{*}{$\begin{array}{l}\text { Rate of active } \\
\text { compound } \\
\left(\mathrm{g} \cdot \mathrm{ha}^{-1}\right)\end{array}$} & \multirow{2}{*}{$\begin{array}{l}\text { No. of } \\
\text { aphids/1 api- } \\
\text { cal shoot be- } \\
\text { fore treatment }\end{array}$} & \multicolumn{4}{|c|}{$\begin{array}{l}\text { No. of aphids per one apical shoot on } 3^{\text {rd }}, 7^{\text {th }}, 14^{\text {th }} \text { and } 21^{\text {st }} \\
\text { day after treatment* }\end{array}$} \\
\hline & & & 3 & 7 & 14 & 21 \\
\hline Control - untreated & - & 99.8 & $135.3 \mathrm{c} * *$ & $107.7 \mathrm{c}$ & $230.8 \mathrm{c}$ & $17.8 \mathrm{~b}$ \\
\hline Spirotetramat & 70 & 115.2 & $14.4 \mathrm{~b}$ & $4.0 \mathrm{a}$ & $0.8 \mathrm{a}$ & $0.1 \mathrm{a}$ \\
\hline Spirotetramat & 100 & 97.1 & $15.7 \mathrm{~b}$ & $24.4 \mathrm{~b}$ & $0.5 \mathrm{a}$ & $0.0 \mathrm{a}$ \\
\hline Thiacloprid & 72 & 101.5 & $7.5 \mathrm{a}$ & $20.4 \mathrm{~b}$ & $14.3 \mathrm{~b}$ & $9.0 \mathrm{~b}$ \\
\hline Thiamethoxam & 25 & 102.4 & $9.3 \mathrm{a}$ & $19.1 \mathrm{~b}$ & $0.5 \mathrm{a}$ & $0.2 \mathrm{a}$ \\
\hline
\end{tabular}

*Date of treatment - 19th of May 2011

**Means followed by the same letter in each column are not significantly different (Newman-Keuls' test, $\mathrm{p}=0.05$ ) 


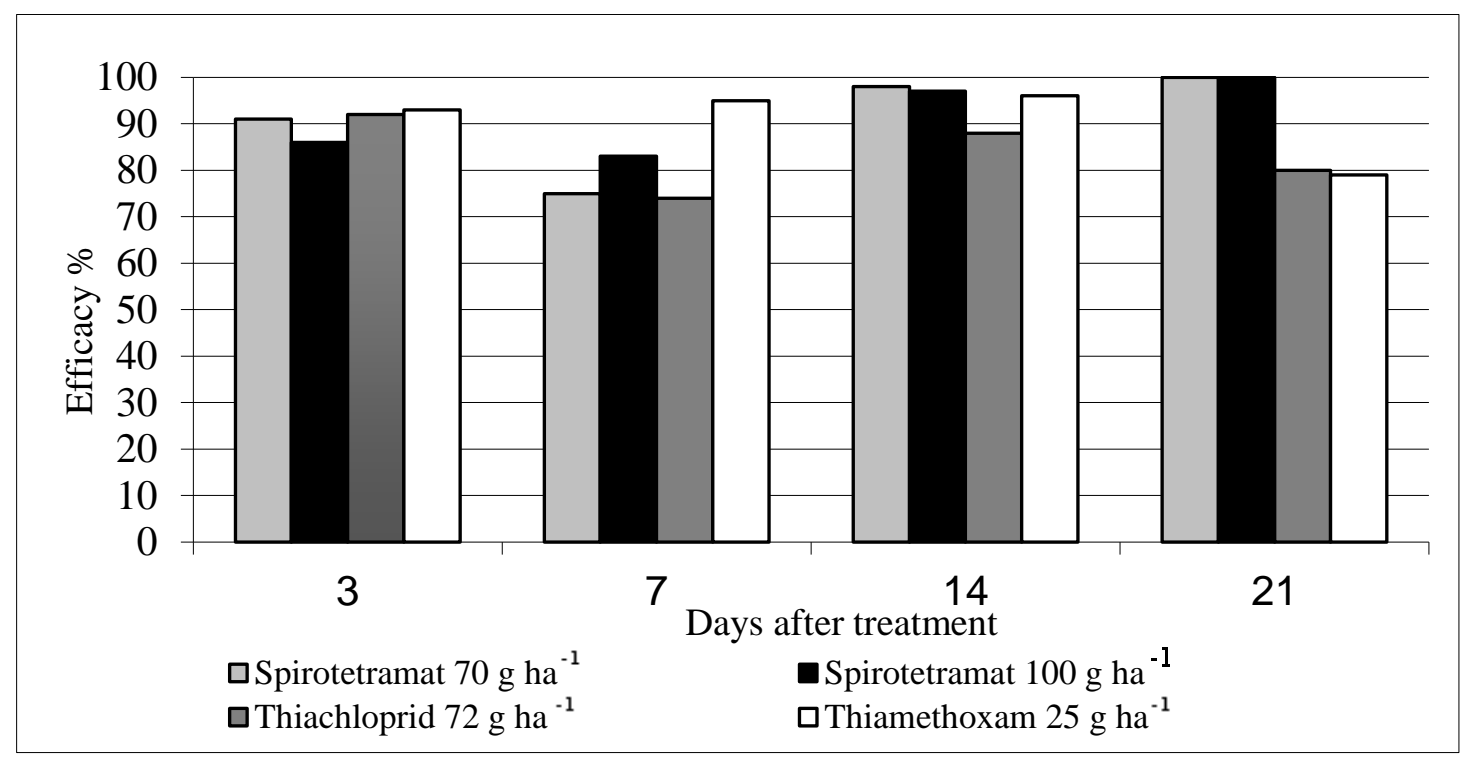

Fig. 2. Efficacy of pesticide treatment in controlling of aphid Hyperomyzus lactucae L. at different check dates after treatment, according to Abbott's formula. Experiment II (Kwasowiec, 2011)

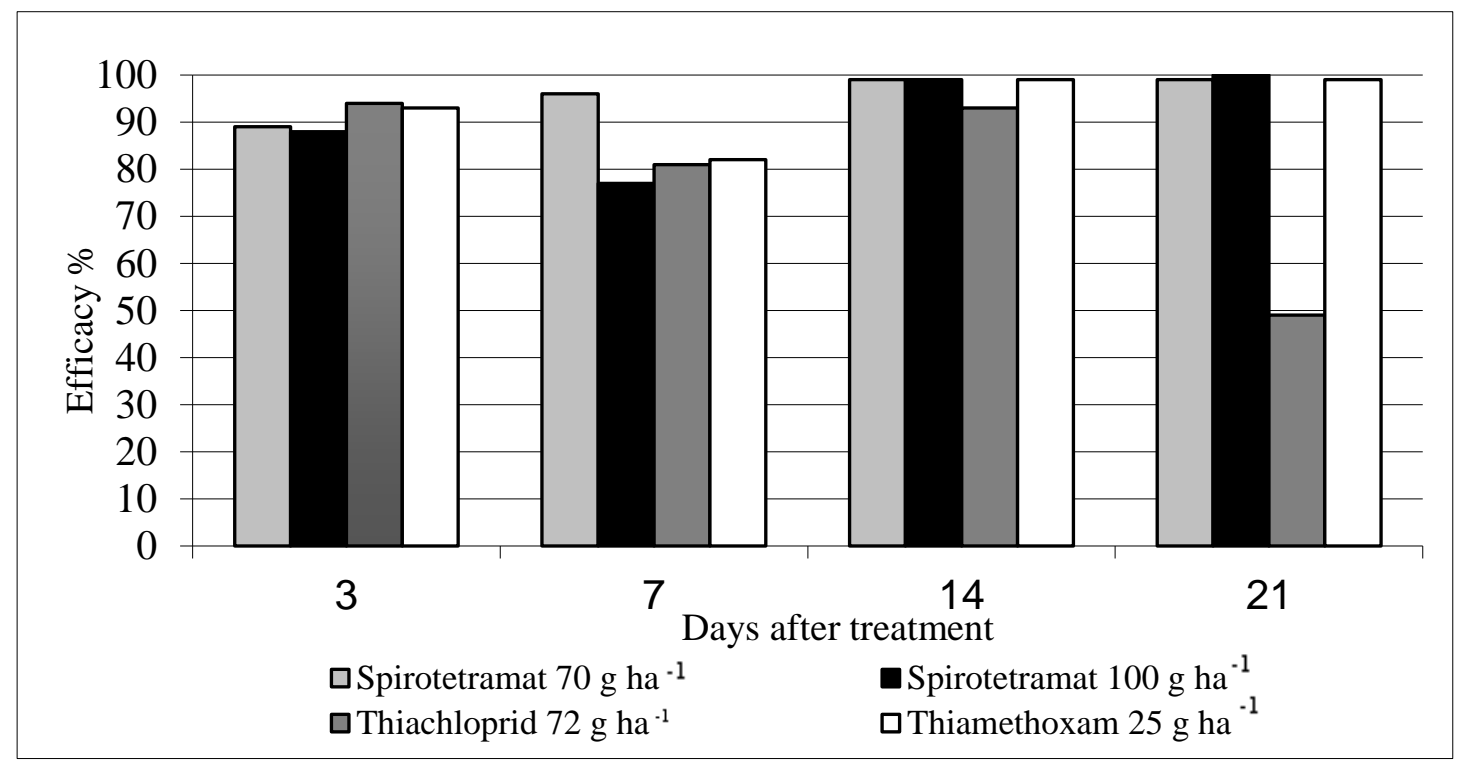

Fig. 3. Efficacy of pesticide treatment in controlling of aphid (Hyperomyzus lactucae L.) at different check dates after treatment, according to Abbott's formula. Experiment III (Zglinna Mała 2011)

In Experiment III on 'Titania' cv., spirotetramat showed high or very high efficacy after 3 and 7 days (77-96\%) and very high - 99-100\% after 14 and 21 days of treatment (Fig. 3). Almost all aphids present on shoots died. The results were similar to those obtained with standard insecticide - thiamethoxam or better than those obtained with thiacloprid. All treatments with spirotetramat resulted in high level of control of aphids on blackcurrant bushes.
The results with spirotetramat confirmed those obtained earlier by Cantoni et al. (2008) regarding the control of aphids Nasonovia ribisnigri Mosley, Aphis pomi De Geer or Eriosoma lanigerum Hausm. The efficacy of spirotetramat, tested as the active ingredient also proved effective in the control of woolly and green apple aphid in apple orchards (Alston \& Lindstrom 2007a, b) and in the control of 
various aphids on strawberry, raspberry and blueberry (Tanigoshi et al. 2009). The results are also in agreement with those obtained in the control of aphids on lettuce by McDougall and Creek (2011) and on celery by Szendrei and Byrne (2013). Reissig and Combs (2009) reported on high affectivity in the controlling of San Jose scale, green apple aphid and wooly apple aphid after treatment with Movento 240 SC. According to Jaworska et al. (2012) Movento 100 SC also showed high efficacy in the control of pear psylla on pear trees.

It is important for the integrated plant protection management that on plants treated with spirotetramat, some beneficial fauna such as Phytoseiidae - larvae and adults as well as eggs were noted. In addition, numerous Coccinellidae (larvae and beetles) and larvae of Syrphidae were observed. The interesting finding was the reduction of big bud mite (Cecidophyopsis ribis) population - the most important pest of blackcurrant in Poland and in other countries, where this crop is commonly grown (Łabanowska et al. 2012). Spirotetramat as Movento 100 SC, following the registration procedures, will be recommended to control aphids directly after blossom of blackcurrant. Application at this time will also reduce the number of buds affected by big bud mite as well as the black currant leaf midge (Dasineura tetensi) and two-spotted spider mite (Tetranychus urticae Koch) (Labanowska 2013, data not published).

\section{CONCLUSIONS}

1. Spirotetramat (as Movento $100 \mathrm{SC}$ ) showed very high and long-lasting efficacy in the control of aphid Hyperomyzus lactucae on currant plantations.

2. Efficacy of spirotetramat was similar or higher as compared with reference substance: pirimicarb (Pirimor $500 \mathrm{WG}$ ), thiamethoxam (Actara $25 \mathrm{WG}$ ) and thiacloprid (Calypso $480 \mathrm{SC}$ ).

3. On bushes treated with spirotetramat, at counting of the aphids, natural enemies of pests like Coccinellidae, Syrphidae and Phytoseiidae were noted.

\section{REFERENCES}

Alston D., Lindstrom T. 2007a. Woolly apple aphid control on apple roots. http://utahpests.usu.edu/ipm/files/uploads/PDFDocs/res07-waa-roots.pdf

Alston D., Lindstrom T. 2007b. Woolly and green apple aphid control trial in apples. Utah Agricultural Research Station Report (12 pp.).

http://utahpests.usu.edu/ipm/files/uploads/PDFDocs/res07-waa-spirotetramat.pdf

Cantoni A., De Maeyer A., Izquierdo Casas J., Niebes J. F., Peeters D., Roffeni S., Silva J., Villalobos A. 2008. Development of Movento $100 \mathrm{SC}^{\circledR}$ on key pests and crops in European countries. Bayer CropScience Journal 61, 2: 349-376.

Cross J.V., Fountain M.T., Harris A., Harrington R. 2010. Autumn control of aphid pests of tree and bush fruit crops. IOBC/WPRS Bulletin 54: 239-242.

Jaworska K., Olszak R.W., Łabanowska B.H., Korzeniowski M. 2012. Efficacy of spirotetramat in the control of pear psylla (Cacopsylla pyri L.) on pear trees in Poland. J. Fruit Ornam. Plant Res. 20(2): 91-106.

Łabanowska B.H., Korzeniowski M. 2012. The chance to control the big bud mite (Cecidophyopsis ribis Westw.) on blackcurrant in Poland with a new product Movento 100 SC. $8^{\text {th }}$ International Conference on Integrated Fruit Production, IFP 2012, Kusadasi, 7-12 October, 2012, Program and Abstract 125 .

Łabanowska B.H., Piotrowski W., Korzeniowski M., Gasparski T. 2013. Efficacy of spirotetramat (Movento $100 \mathrm{SC}$ ) in the control of strawberry mite (Phytonemus pallidus) on strawberry plantations in Poland. Future IPM in Europe. Riva del Garda, Italy 19-21 March, 2013, Book and Abstract.

McDougall S., Creek A. 2011. Currant lettuce aphid. http://www.dpi.nsw.gov.au/_data/assets/pdf_file/0008/57572/Currant-lettuce-aphid.pdf

Mitchell C., Brennan R.M., Cross J.V., Johnson S.N. 2011. Review article. Arthropod pests of currant and gooseberry crops in the U.K.: their biology, management and future prospects. Agric. For. Entomol. 13: 221-237. The Royal Entomological Society. DOI: 10.1111/j.1461-9563. 2010.00513.x.

Reissig W.H., Combs D. 2009. Movento 240 SC for control of San Jose Scale, Green Apple Aphid and Woolly Apple Aphid. pp. 26-27. https://hrt.msu.edu/glfw/GLFW_2009_Abstracts/2009_13.pdf 
Szendrei Z., Byrne A.M. 2013. Aphid and leafhopper control in celery. http://vegetable.ent.msu.edu/images/CELERY-Report-Jan-28-2013.pdf

Tanigoshi L.K., Spitler H., Gerdeman B.S. 2009. Comparative efficacy of experimental aphicides for strawberry, raspberry and blueberry aphid control. http://www.mountvernon.wsu.edu/ENTOMOLOGY/Documents/DuPont\%20aphids.09.doc

Wnuk A., Medvey M. 1986. Syrphid predators (Diptera, Syrphidae) occurring in colonies of aphids (Homoptera, Aphidinea) on currants. Pol. Pis. Ent. 56, 1: 209-215.
Wojciechowicz-Żytko E., Jankowska B. 2011. Aphids and their predators occurring on some shrubs in the Botanic Garden of the Jagiellonian University in Krakow. Aphids and other Hemipterous Insects 17: 145-154.

Wojciechowicz-Żytko E. 2009. Predatory syrphids (Diptera, Syrphidae) and ladybird beetles (Coleoptera, Coccinellidae) and the colonies of Aphis fabae Scopoli, 1763 (Hemiptera, Aphidoidea) on Philadelphus coronarius L. Aphids and other Hemipterous Insects, 15: 168-181. 